\title{
Effect of Different Water Qualities On Clarias Gariepinus Growth And Survival
}

\author{
*Imam, T. S., Abdullahi, Z. D. and Sani, A. \\ Biological Sciences Department, Bayero University, \\ Kano, PMB 3011, Kano State, Nigeria
}

Accepted January, 2019 and Published February, 2019

\begin{abstract}
Growth and survival of Clarias gariepinus in different water qualities were investigated. Initially, water of equal quality was used for the experiment, later the quality of water varies due to period of water change, (daily-T4, weekly-T3, bi-weekly-T2 and monthly-T1). Physico-chemical parameters were analyzed. Two hundred and forty (240) seven weeks old fingerlings of $C$. gariepinus were randomly distributed into 12 plastic tanks. Poor growth of C. gariepinus was observed in the treatment tanks (T1, T2 and T3), compared with growth of fish in the control (T4) which was progressive as indicated by the higher value of condition factor. Treatment tanks had significantly $(P<0.05)$ higher EC, TDS, Turbidity, Ammonia, Nitrate and Nitrite and significantly $(P<0.05)$ lower DO than culture water in control container. Slight growth was recorded for fish in $T 1$ and T2 until the second week when drop in fish weight was observed. This study has shown that poor water quality can reduce growth rate and survival of C. gariepinus.
\end{abstract}

Key words: Clarias. gariepinus, growth, physicochemical, survival, water quality,

*Corresponding Author's

E-mail: tsimam.bio@buk.edu.ng

Tel: 08133382562 


\section{INTRODUCTION}

Fish is an inexpensive source of protein and an important cash crop in many regions of world and water is the physical support in which they carry out their life functions such as feeding, swimming, breeding, digestion and excretion.

Fish are subjected to stress every day. Changes in culture system, water quality, environment, fish physiology and social condition constitute stress factors, which disturbs the fine internal balance, homeostasis, and has further detrimental effects on behavior, survival, growth, reproduction, immune function and disease tolerance.

Water quality plays a role in the distribution of fish. ${ }^{5}$ The importance of measuring physical, chemical and biological variables was considered at the Technical Consultation on Enhancement of Fisheries of Small Water Bodies in Harare. The Physico-chemical characteristics of water are important parameters as they may directly or indirectly affect its quality and consequently its suitability for the distribution and production of fish and other aquatic animals. $^{6}$

Thus, this research is aimed at determining the growth rate of Clarias gariepinus at different water qualities.

\section{MATERIALS AND METHODS}

\section{The study area}

The study was conducted in the fish aquarium, Biological Science Department of Bayero University Kano, Nigeria. It was conducted for the period of four weeks ( 28 days) from

$2^{\text {nd }}$ December 2014 to $30^{\text {th }}$ December 2014 .

\section{Sample Collection}

Source of Fingerlings
Fingerling of pure breed Claries gariepinus were collected from the hatchery unit of 313 Farm limited Zara Kantudu, along Danladi Nasidi, Kumbotso L.G.AKano Nigeria.

\section{Fingerlings Transportation}

Fish were transported early in the morning from the farm in a 25 litters jar can containing about 10 liters of water. Small quantities of fish bit plus were added in the water which acts as antis tress during transportation.

\section{Fingerlings Selection}

The fingerling were selected after sorting the bigger once from the smaller once, and they were selected on the assumption that they are of the same size.

\section{Experimental design}

The experimental set-up consisted of twelve plastic tanks of size $30 \mathrm{~cm}$ by $40 \mathrm{~cm}$ and $25 \mathrm{~L}$ capacity situated in the fish aquarium Biological Science Department, Bayero University Kano. Before stocking, parasite and other predators were eliminated by washing the plastic tanks with sodium chloride $(\mathrm{NaCl})$ and rinse with fresh water. Two hundred and forty (240) seven week old fingerlings of Claries gariepinus ranging in total length $7.28 \pm 0.21 \mathrm{~cm}$ to $7.68 \pm 0.27 \mathrm{~cm}$ and weight $3.40 \pm 0.09 \mathrm{~g}$ to $4.05 \pm 0.16 \mathrm{~g}$ were used. Borehole water for this research was collected in the aquarium and carried to the laboratory for physico-chemical analysis (Temperature, Electrical conductivity, TDS, $\mathrm{DO}_{2}$, Turbidity, Ammonia, Nitrate, Nitrite and $\mathrm{pH}$ ) .Twenty (20) fingerlings each were randomly distributed into four (4) different tanks with their replicate labeled: Daily (control/T4), weekly(T3), bi-weekly(T2) and monthly(T1) having $100 \%$ water exchange daily, weekly, bi-weekly and monthly respectively. Each tank contains about 20L borehole water for the research. Dead fish were picked weekly and recorded. 


\section{Feeding Trial}

Feeding was done twice daily at $5 \%$ of the body weight. The feed for each day was divided into 2 parts administered at 01000 and $17000 \mathrm{~h}$ for a period of 28 days. The mean weight $(\mathrm{g})$ and total length $(\mathrm{cm})$ of the fish from each treatment and its replicates were measured weekly. The feeding rate was re-calculated every week to accommodate weight changes and mortality that would have occurred.

\section{Fish Growth and Survival}

For this study, growth was expressed as Weight gain, Relative Growth Rate, Specific Growth Rate, Condition Factor ${ }^{7}$ and Survival rate. ${ }^{8}$ Total and standard lengths of the fish were determined from the mouth snout to the tip of the caudal fin and hypural bone, respectively as recommended by Reed et al. ${ }^{9}$ Weight of the fish was determined with digital weighing balance. The well being of the fish was known as condition factor which was determined by the formula recommended by Warthingston and Richardo. ${ }^{10}$

\section{Weight Gain (WTG) $=\mathrm{W}_{2}-\mathrm{W}_{1}$}

Where $\mathrm{W}_{1}=$ Initial mean weight-

$$
\mathrm{W}_{2}=\text { final mean weight }
$$

Percentage Weight Gain (\%) (RGR) $=100$ $(\mathrm{Y}-\mathrm{X}) / \mathrm{X}$

Where $\mathrm{X}=$ Initial Mean Body Weight

$\mathrm{Y}=$ Final Mean Body Weight

Specific Growth Rate (SGR) $=\mathrm{LnWT}-\mathrm{LnWt} /$

$\mathrm{T} \times 100$

Where

$\mathrm{Ln}=$ Natural log

$\mathrm{WT}=$ final weight

$\mathrm{Wt}=$ Initial weight

$\mathrm{T}=$ Time interval

Average Daily Growth (ADG) $=\mathrm{W}_{2}-\mathrm{W}_{1} / \mathrm{T}$
Where $\mathrm{W}_{2}=$ Final Mean Weight

$$
\begin{aligned}
& \mathrm{W}_{1}=\text { Initial Mean Weight } \\
& \mathrm{T}=\text { Rearing Period }
\end{aligned}
$$

\section{Condition factor $(\mathrm{K})=100 \times \mathrm{W} / \mathrm{L}^{3}$}

Where

$\mathrm{W}=$ Weight

$\mathrm{L}^{3}=$ Final length

Survival (\%)(S) $=\mathrm{N}_{1}$ X 100/ $\mathrm{N}_{0}$

Where

$\mathrm{N}_{1}=$ final number of fish at the end of experiment.

$\mathrm{N}_{0}=$ Initial No of fish at the beginning of experiment.

\section{Determination of Physicochemical Parameters \\ $\mathrm{DO}_{2}$}

The dissolved oxygen in each experimental container was monitored and determined using HI 9146 microprocessor dissolved Oxygen Meter.

\section{Electric Conductivity, TDS and pH}

All these parameter were measures using $\mathrm{HI}$ 255 Combine Meter pH/TDS Conductivity meter.

\section{Temperature}

Temperature for this research was measured insitu using mercury in glass thermometer

\section{Ammonium-Nitrogen, Nitrate-Nitrogen and Nitrite-Nitrogen}

This was measured using microgelder distillation and titration method.

\section{Statistical analysis}

In Stat was used in analyzing the data obtained. Mean and standard error were used to assess the spread of the data. The mean of parameters \pm SE and one-way Analysis of Variance (ANOVA) followed by a post hoc multiple comparison (Tukey's test) were calculated to compare the mean values of observation based on tanks for test of significance at $\mathrm{P}<0.05$. 


\section{RESULTS}

Table 1: Mean initial, final and weigh $\mathrm{t} /$ length of Clarias gariepinus at different water qualities.

\begin{tabular}{llllll}
\hline S/N & Mean value & T1 & T2 & T3 & T4 \\
\hline 1 & Initial weight (g) & $3.83 \pm 0.19^{\mathrm{a}}$ & $3.40 \pm 0.09^{\mathrm{a}}$ & $3.44 \pm 0.14^{\mathrm{a}}$ & $4.05 \pm 0.16^{\mathrm{a}}$ \\
2 & Final weight (g) & $2.96 \pm 0.02^{\mathrm{a}}$ & $2.49 \pm 0.05^{\mathrm{a}}$ & $4.68 \pm 0.36^{\mathrm{b}}$ & $9.89 \pm 0.01^{\mathrm{c}}$ \\
3 & Weight gain (g) & $-0.87 \pm 0.18^{\mathrm{a}}$ & $-0.91 \pm 0.06^{\mathrm{a}}$ & $1.24 \pm 0.30^{\mathrm{b}}$ & $5.84 \pm 0.15^{\mathrm{c}}$ \\
4 & Initial length (cm) & $7.68 \pm 0.27^{\mathrm{a}}$ & $7.28 \pm 0.21^{\mathrm{a}}$ & $7.47 \pm 0.13^{\mathrm{a}}$ & $7.33 \pm 0.33^{\mathrm{a}}$ \\
5 & Final length (cm) & $7.75 \pm 0.25^{\mathrm{a}}$ & $7.34 \pm 0.22^{\mathrm{a}}$ & $8.58 \pm 0.12^{\mathrm{b}}$ & $9.99 \pm 0.02^{\mathrm{c}}$ \\
6 & length gain(cm) & $0.07 \pm 0.02^{\mathrm{a}}$ & $0.06 \pm 0.01^{\mathrm{a}}$ & $1.12 \pm 0.07^{\mathrm{b}}$ & $2.18 \pm 0.0^{\mathrm{c}}$
\end{tabular}

Mean values were obtained from three replicates.

The same superscripts in a row show no significant difference.

Table 2: Summary of growth indices and condition factor of $C$. gariepinus at different water qualities for an experimental period of 4 weeks.

\begin{tabular}{llllll}
\hline S/N & Mean Value & T1 & T2 & T3 & T4 \\
\hline 1 & Condition Factor & $0.64 \pm 0.07^{\mathrm{a}}$ & $0.63 \pm 0.04^{\mathrm{a}}$ & $0.74 \pm 0.07^{\mathrm{a}}$ & $1.00 \pm 0.00^{\mathrm{b}}$ \\
2 & Relative Growth Rate & $-22.44 \pm 3.71^{\mathrm{a}}$ & $-26.71 \pm 1.35^{\mathrm{a}}$ & $35.57 \pm 5.76^{\mathrm{b}}$ & $145.10 \pm 9.88^{\mathrm{c}}$ \\
3 & Specific Growth Rate & $-0.79 \pm 0.14^{\mathrm{a}}$ & $-0.98 \pm 0.06^{\mathrm{a}}$ & $0.95 \pm 0.13^{\mathrm{b}}$ & $2.76 \pm 0.12^{\mathrm{c}}$ \\
4 & Average Daily Growth & $-0.06 \pm 0.01^{\mathrm{a}}$ & $-0.07 \pm 0.00^{\mathrm{a}}$ & $0.09 \pm 0.02^{\mathrm{b}}$ & $0.41 \pm 0.01^{\mathrm{c}}$ \\
\hline
\end{tabular}

Mean values were obtained from three replicates.

Same superscripts in a row show no significant difference.

Table 3: Mean Physico -chemical Parameters of Control and Treatment tanks of C. gariepinus at different water qualities.

\begin{tabular}{llllll}
\hline $\mathrm{S} / \mathrm{N}$ & Parameters & $\mathrm{T} 1$ & $\mathrm{~T} 2$ & $\mathrm{~T} 3$ & $\mathrm{~T} 4$ \\
\hline 1 & Temperature $\left({ }^{0} \mathrm{C}\right)$ & $23.23 \pm 0.29^{\mathrm{a}}$ & $23.23 \pm 0.29^{\mathrm{a}}$ & $23.23 \pm 0.29^{\mathrm{a}}$ & $23.23 \pm 0.29^{\mathrm{a}}$ \\
2 & $\mathrm{pH}$ & $7.39 \pm 0.07^{\mathrm{a}}$ & $7.34 \pm 0.05^{\mathrm{a}}$ & $7.21 \pm 0.08^{\mathrm{a}}$ & $7.28 \pm 0.11^{\mathrm{a}}$ \\
3 & $\mathrm{DO}_{2}(\mathrm{ppm})$ & $0.67 \pm 0.04^{\mathrm{a}}$ & $0.68 \pm 0.04^{\mathrm{a}}$ & $3.28 \pm 0.12^{\mathrm{b}}$ & $5.90 \pm 0.11^{\mathrm{c}}$ \\
4 & $\mathrm{E} . \mathrm{C}(\mu \mathrm{S} / \mathrm{cm})$ & $409.00 \pm 9.50^{\mathrm{a}}$ & $404.33 \pm 3.48^{\mathrm{a}}$ & $231.13 \pm 10.92^{\mathrm{b}}$ & $65.40 \pm 7.81^{\mathrm{c}}$ \\
5 & Turbidity (NTU) & $420.00 \pm 1.73^{\mathrm{a}}$ & $410.33 \pm 1.45^{\mathrm{b}}$ & $183.33 \pm 1.76^{\mathrm{c}}$ & $25.33 \pm 1.76^{\mathrm{d}}$ \\
6 & $\mathrm{TDS}(\mathrm{mg} / \mathrm{l})$ & $356.67 \pm 18.56^{\mathrm{a}}$ & $336.67 \pm 18.56^{\mathrm{a}}$ & $106.67 \pm 3.33^{\mathrm{b}}$ & $50.00 \pm 0.00^{\mathrm{b}}$ \\
7 & $\mathrm{NH}_{3}-\mathrm{N}(\mathrm{mg} / \mathrm{l})$ & $27.74 \pm 1.47^{\mathrm{a}}$ & $23.72 \pm 0.86^{\mathrm{b}}$ & $13.06 \pm 0.26^{\mathrm{c}}$ & $3.07 \pm 0.09^{\mathrm{d}}$ \\
8 & $\mathrm{NO}_{2}-\mathrm{N}(\mathrm{mg} / 1)$ & $6.57 \pm 0.15^{\mathrm{a}}$ & $6.34 \pm 0.09^{\mathrm{a}}$ & $4.35 \pm 0.28^{\mathrm{b}}$ & $0.79 \pm 0.17^{\mathrm{c}}$ \\
9 & $\mathrm{NO}_{3}-\mathrm{N}(\mathrm{mg} / \mathrm{l})$ & $81.40 \pm 1.33^{\mathrm{a}}$ & $77.25 \pm 1.06^{\mathrm{a}}$ & $48.72 \pm 1.66^{\mathrm{b}}$ & $3.77 \pm 0.27^{\mathrm{c}}$ \\
\hline
\end{tabular}

Mean values were obtained from three replicates.

Same superscripts in a row show no significant difference. 
Table 4: Mean Survival of C. gariepinus at Different Water Qualities Parameters

\begin{tabular}{llcccc}
\hline S/N & Mean value & $\mathrm{T} 1$ & $\mathrm{~T} 2$ & $\mathrm{~T} 3$ & $\mathrm{~T} 4$ \\
\hline 1 & $\begin{array}{l}\text { Initial number } \\
\text { of fish }\end{array}$ & $20.00 \pm 0.00^{\mathrm{a}}$ & $20.00 \pm 0.00^{\mathrm{a}}$ & $20.00 \pm 0.00^{\mathrm{a}}$ & $20.00 \pm 0.00^{\mathrm{a}}$ \\
2 & $\begin{array}{l}\text { Final number } \\
\text { of fish }\end{array}$ & $00.00 \pm 0.00^{\mathrm{a}}$ & $00.00 \pm 0.00^{\mathrm{a}}$ & $09.00 \pm 0.07^{\mathrm{b}}$ & $20.00 \pm 0.05^{\mathrm{c}}$ \\
3 & $\begin{array}{l}\text { Percentage of } \\
\text { survival }\end{array}$ & $00.00 \pm 0.00^{\mathrm{a}}$ & $0.00 \pm 0.00^{\mathrm{a}}$ & $45.00 \pm 0.07^{\mathrm{b}}$ & $100.00 \pm 0.05^{\mathrm{c}}$ \\
\hline
\end{tabular}

Mean values were obtained from three replicates.

The same superscripts in a row show no significant difference.

\section{DISCUSSION}

The temperature recorded was $23.23^{\circ} \mathrm{C} \pm 0.29$, However, the ideal range of temperature is between $20^{\circ} \mathrm{C}-25^{\circ} \mathrm{C}$ and the acceptable range is $20^{\circ} \mathrm{C}-30^{\circ} \mathrm{C}$ (Alabaster and Lloyd, 1980). Hence, temperature exacts no effect in this experiment. No significant difference in temperature between control and treatment tanks $(p>0.05)$ because the experiment was conducted during cold season $\left(2^{\text {nd }}\right.$ Dec. $-1^{\text {st }} J a n$.) probably, the temperature is influenced by the season.

$\mathrm{pH}$ also exert no effect in this research because it fall within the range recommended suitable by Santhosh and Singh, ${ }^{11}$ which state that the suitable $\mathrm{pH}$ range for fish culture is between 6.7 and 9.5 and ideal $\mathrm{pH}$ level is between 7.5 and 8.5 and above or below this is stressful to the fishes. Low dissolved oxygen in $\mathrm{T} 1, \mathrm{~T} 2$ and $\mathrm{T} 3$ $(0.67 \pm 0.04 \mathrm{mg} / \mathrm{L}, 0.68 \pm 0.04 \mathrm{mg} / \mathrm{L}$ and $3.28 \pm 0.12 \mathrm{mg} / \mathrm{L}$ respectively) is responsible for poor growth and mortality. Boyd and Lichtkoppler, ${ }^{12}$ reported that fish may survive but have slower growth rate with low dissolved oxygen. Okaeme, ${ }^{13}$ also noted that low dissolved oxygen level can be lethal, resulting in acute fish anoxia leading to retarded growth of embryo, juveniles and eventual mortality. Jhingran, ${ }^{14}$ found that growth and production is optimum at more than $5 \mathrm{mg} / \mathrm{L}$ of dissolved oxygen, above $5 \mathrm{mg} / \mathrm{L}$, almost all aquatic organisms can survive indefinitely. Dissolved oxygen levels were significantly lower $(\mathrm{p}<0.05)$ in treatment tanks due to respiration by fish in these tanks.

All values of EC obtained fall within the range recommended by Stone and Thomforde, ${ }^{15}$ which state the desirable range of $100-2,000$ $\mu \mathrm{S} / \mathrm{cm}$ and acceptable range $30-5,000 \mu \mathrm{S} / \mathrm{cm}$ for pond fish culture. Hence, higher value of EC in $\mathrm{T} 1, \mathrm{~T} 2$ and $\mathrm{T} 3(409 \pm 9.50 \mu \mathrm{S} / \mathrm{cm}$, $404.33 \pm 3.48 \mu \mathrm{S} / \mathrm{cm}$ and $231.13 \pm 10.92 \mu \mathrm{S} / \mathrm{cm}$ respectively) do not affect fish growth and survival.

The high amount of TDS in T1, T2 and T3 $(356.67 \pm 18.56 \mathrm{mg} / \mathrm{L}, 336.67 \pm 18.56 \mathrm{mg} / \mathrm{L}$ and $106.67 \pm 3.33 \mathrm{mg} / \mathrm{L}$ respectively) increases the water density and influences osmoregulation of freshwater organisms and reduces solubility of gases.

Stone and Thomforde, ${ }^{15}$ stated the acceptable range as Total $\mathrm{NH}_{3} \mathrm{~N}$ : Less than $4 \mathrm{mg} / \mathrm{L}$, control has value within acceptable range $(3.07 \pm 0.09 \mathrm{mg} / \mathrm{L})$ and $\mathrm{T} 1, \mathrm{~T} 2$ and $\mathrm{T} 3$ have higher values $(27.74 \pm 1.47 \mathrm{mg} / \mathrm{L}$, $23.72 \pm 0.86 \mathrm{mg} / \mathrm{L}$ and $13.06 \pm 0.26 \mathrm{mg} / \mathrm{L}$ respectively) resulting in mortality and poor growth. According to Alabaster and Lloyd, ${ }^{16}$ ammonia poisoned fish congregates close to the water surface, gasp for air and are restless. In some cases, hemorrhages occur mainly at the base of the pectoral fins. 
Stone and Thomforde, ${ }^{15}$ suggested that the desirable range of $\mathrm{NO}_{2}^{-}$is $0-1 \mathrm{mg} / \mathrm{L}$ and acceptable range of less than $4 \mathrm{mg} / \mathrm{L}$. Higher value recorded in $\mathrm{T} 1, \mathrm{~T} 2$ and $\mathrm{T} 3$ $(6.57 \pm 0.15 \mathrm{mg} / \mathrm{L}, 6.34 \pm 0.09 \mathrm{mg} / \mathrm{L}$ and $4.35 \pm 0.28 \mathrm{mg} / \mathrm{L}$ respectively) result in poor growth and mortality. Vamos and Szollozy, ${ }^{17}$ documented that nitrite poisoned fish.

There is significant difference $(\mathrm{p}<0.05)$ between the control and experimental tanks in Ammonia, Nitrate and Nitrite due to accumulation of metabolic waste in the experimental tanks.

The high levels of Turbidity, TDS, $\mathrm{NH}_{4}-\mathrm{N}, \mathrm{NO}_{3}-$ $\mathrm{N}, \mathrm{NO}_{2}-\mathrm{N}$ and the low level of DO observed may have been responsible for the poor growth rate recorded in the treatment tanks. Low water quality has been reported to clog fish gills reducing resistance to diseases, lowering growth rate and affecting egg and larval development. ${ }^{18}$

In table 3, no significant different in condition factor among T1, T2 and T3 because all fish in these tanks were not doing well. According to Bagenel and Tesch, ${ }^{7}$ the condition factor is a length-weight relationship that indicates the well-being of the fish. The lower the condition factors the poorer the well being of the fish.

\section{Conclusion}

The physico-chemical water parameters in T4 showed that water is within the range recommended for fresh water fish (favorable for survival of $C$. gariepinus), hence produce the highest weight gain and the highest survival and gave the best benefit to the farmer. Since the whole aim of growing fish at different water quality is to achieve the best growth for profit maximization to the farmer, this study has demonstrated that $C$. gariepinus can be grown locally as long as there is good water quality and adequate feeding.

\section{Recommendations}

These include the following:

1. Monitor water quality parameters.

2. Ensure that environmental factors are properly managed and regulated.

3. Proper treatment of wastes generated by aquaculture activities (faeces and unconsumed feed).

4. Control eutropication.

5. Proper fertilizer application.

\section{REFERENCES}

1. Bronmark C, Hansson LA, The Biology of Lakes and Ponds, Oxford University Press, Oxford: pp 285, 2005.

2. Tanck MWT, Booms GHR, Eding EH, Bonga SE, Komen J. Cold shocks: a stressor for common carp. J Fish Bio 2000; 57: 881-894.

3. Goos HJT, Consten D. Stress adaptation, cortisol and pubertal development in the male common carp Cyprinus carpio, Molecular \& Cellular End. 2002; 197(1-2):105-16

4. Chen C, Wooster GA, Bowser PR. Comparative blood chemistry and histopathology of tilapia infected with Vibrio vulnificus or Streptococcus iniae or exposed to carbon tetrachloride, gentamicin or copper sulfate. Aquaculture, 2004; 239:421-443.

5. Welcomme RL. Fisheries Ecology of Flood Plain Rivers, Longman. London: pp 317, 1979.

6. Moses BS. Introduction to Tropical Fisheries, Ibadan University Press, 
UNESCO/ICSU, Part: pp 102-105, 1983.

7. Bagenal TB, Tesch. Methods of Assessment of Fish Production in Fresh Water. Blackwell Science Publication Oxford IBP. Handbook No. 3: pp 35, 1978.

8. Fasakin EA, Falayi AA, Eyo AA. Inclusion of poultry manure in the diet for nile tilapia (O. niloticus)L. J of Fish Tech, 2000; 2: pp 51-56.

9. Reed W, Burcharol J, Hopson AJ, Jeunes J, Yaro I. Fish and Fisheries of Northern Nigeria. Gaskiya Cooperation Zaria, Nigeria, 1967.

10. Warthington BE, Richardo CK. Scientific result of the cambridge expedition on the east Africa lakes Redolf and lake Betino. J. Linnsoc Zool. 1930: pp 267:353.

11. Santhos B, Singh NP. Guidelines for Water Quality Management for Fish Culture in Tripura, ICAR Research Complex for NEH Region, Tripura Centre, Pub. No. 29, 2007

12. Boyd CE, Lichtkopper F. Water Quality Management in Fish Ponds. Research and Development series No. 22, International Centre for Aquaculture
(JCAA) Experimental station, Auburn University,Alabama: pp 45-47, 1979.

13. Okaeme AN. Prospects of and problems of fish water ponds fertilization using animal droppings subsistence fish farming, The Nig. $J$. Agric Extension, 1990; 28: 58-64.

14. Jhingran VG. Fish and Fisheries of India. Hindustan Publishing Corporation, Delhi, India. pp. 79-100, 1988.

15. Stone NM, Thomforde HK. Understanding your Fish Pond Water Analysis Report. Cooperative Extension Program, University of A rkans as at P in e B l u ff Aquaculture/Fisheries, 2004.

16. Alabaster JS, Lloyd R. Water Quality Criteria for Freshwater Fish. Butterworths.pp: 279, 1980.

17. Vamos R. Szollozy G. There is not a danger of ammonia intoxication of fish if there is enough oxygen in water. Halaszat. 1974; 20 (4): 124 (in Hungarian).

18. Over S, Adeniyi HA. A Simple Guide to Quality Management in Fish Pond, National Institute for Freshwater Fisheries Research, Technical Report Series No. 23:29, 1990. 